\title{
73. On the Germination of Pollen Obtained from Mosaic Tobacco Plants.
}

\author{
By Shigekatsu HiraYAmA.
}

(Comm. by S. IKeno, M.I.A., July 13, 1936.)

Kostoff ${ }^{2)}$ reported the female sterility of tobacco plants affected by a certain mosaic virus and also the abnormality in the function of the germination of pollen. In his case, the occurrence of the abundant abortive pollen resulted in the low percentage of germination.

The writer carried out the germination experiments with the pollen of the healthy and mosaic tobacco plants (Nicotiana tabacum, Hatano variety), which had been grown in the green house. One series of the seedlings were inoculated with the expressed juice of mosaic tobacco leaves by means of rubbing method, and both series of plants, healthy and diseased, were grown in pots until blooming under the same conditions. Agar medium containing $\mathbf{5}$ per cent glucose was poured into sterilized Petri-dishes, and after it became cool, pollen was sown on it. The dishes were incubated in a thermostat at about $25^{\circ} \mathrm{C}$ for 6 hours, and then a few drops of formalin were added on the inner side of the lids of the dishes, and the dishes were covered with them to prevent the further development of the germ tubes of the pollen. A bit of the agar sheet on which pollen was sown was cut off and laid on a slide glass, and pollen was stained with cotton-blue solution (1\%) and examined under the microscope.

The results of the experiments are shown in the following Tables.

TABle I. Germination of Pollen Taken from Healthy Plants.

\begin{tabular}{|c|c|c|c|c|c|c|c|c|c|}
\hline \multirow{3}{*}{$\begin{array}{l}\text { No. } \\
\text { of } \\
\text { Exp. }\end{array}$} & \multicolumn{3}{|c|}{$\begin{array}{l}\text { Number Atortive Pollen } \\
\text { of }\end{array}$} & \multicolumn{6}{|c|}{ Apparently Normal Pollen } \\
\hline & \multirow{2}{*}{$\begin{array}{c}\text { Pollen } \\
\text { Ob- } \\
\text { served }\end{array}$} & \multirow{2}{*}{ Number } & \multirow{2}{*}{$\%$} & \multirow{2}{*}{ Number } & \multirow{2}{*}{$\%$} & \multicolumn{2}{|c|}{ Germinated } & \multicolumn{2}{|c|}{ Not Germinated } \\
\hline & & & & & & Number & $\%$ & Number & $\%$ \\
\hline I & 1014 & 55 & 5.42 & 959 & 94.58 & 705 & 73.51 & 254 & 26.49 \\
\hline II & 1000 & 111 & 11.10 & 889 & 88.90 & 493 & 55.46 & 396 & 44.54 \\
\hline III & 1000 & 165 & 16.50 & 835 & 83.50 & 227 & 27.19 & 608 & 72.81 \\
\hline IV & 1021 & 192 & 18.05 & 829 & 81.20 & 502 & 60.56 & 327 & 39.45 \\
\hline $\mathrm{V}$ & 1000 & 77 & 7.70 & 923 & 92.30 & 411 & 44.53 & 512 & 55.47 \\
\hline VI & 1000 & 126 & 12.60 & 874 & 87.40 & 377 & 43.14 & 497 & 56.86 \\
\hline VII & 1000 & 123 & 12.30 & 877 & 87.70 & 382 & 43.56 & 495 & 56.44 \\
\hline VIII & 1000 & 110 & 11.00 & 890 & 89.00 & 525 & 58.99 & 365 & 41.01 \\
\hline IX & 1000 & 117 & 11.70 & 883 & 88.30 & 510 & 57.76 & 373 & 42.24 \\
\hline $\mathrm{X}$ & 1000 & 95 & 9.50 & 905 & 90.50 & 540 & 59.67 & 365 & 40.33 \\
\hline \multicolumn{2}{|c|}{ Average } & & 11.59 & & 88.34 & & 52.44 & & 47.56 \\
\hline
\end{tabular}

1) The present investigation was done in the Tokugawa Institute for Biological Research.

2) Kostoff, D.: Genetica, 15 (1933), 103-114. 
TABLE II. Germination of Pollen Taken from Diseased Plants.

\begin{tabular}{|c|c|c|c|c|c|c|c|c|c|}
\hline \multirow{3}{*}{$\begin{array}{c}\text { No. } \\
\text { of } \\
\text { Exp. }\end{array}$} & \multirow{3}{*}{$\begin{array}{c}\text { Number } \\
\text { of } \\
\text { Pollen } \\
\text { Ob- } \\
\text { served }\end{array}$} & \multicolumn{2}{|c|}{ Abortive Pollen } & \multicolumn{6}{|c|}{ Apparently Normal Pollen } \\
\hline & & \multirow{2}{*}{ Number } & \multirow{2}{*}{$\%$} & \multirow{2}{*}{ Number } & \multirow{2}{*}{$\%$} & \multicolumn{2}{|c|}{ Germinated } & \multicolumn{2}{|c|}{ Not Germinated } \\
\hline & & & & & & Number & $\%$ & Number & $\%$ \\
\hline I & 1000 & 33 & 3.30 & 967 & 96.70 & 803 & 83.04 & 164 & 16.96 \\
\hline II & 1000 & 89 & 8.90 & 911 & 91.10 & 728 & 79.91 & 183 & 20.09 \\
\hline III & 1000 & 58 & 5.80 & 942 & 94.20 & 773 & 82.06 & 169 & 17.94 \\
\hline IV & 1000 & 56 & 5.60 & 944 & 94.40 & 761 & 80.61 & 183 & 19.39 \\
\hline V & 1000 & 119 & 11.90 & 881 & 88.10 & 820 & 93.08 & 61 & 6.92 \\
\hline VI & 1000 & 113 & 11.30 & 887 & 88.70 & 732 & 82.53 & 155 & 17.47 \\
\hline VII & 1000 & 214 & 21.40 & 786 & 78.60 & 76 & 9.67 & 710 & 90.33 \\
\hline VIII & 1000 & 80 & 8.00 & 920 & 92.00 & 413 & 44.89 & 507 & 55.11 \\
\hline IX & 1000 & 178 & 17.80 & 822 & 82.20 & 422 & 51.34 & 400 & 48.66 \\
\hline $\mathrm{X}$ & 1000 & 155 & 15.50 & 845 & 84.50 & 399 & 47.22 & 446 & 52.78 \\
\hline $\mathrm{XI}$ & 1047 & 102 & 9.74 & 945 & 90.26 & 495 & 52.38 & 450 & 47.62 \\
\hline XII & 1016 & 141 & 13.88 & 875 & 86.12 & 515 & 58.86 & 360 & 41.14 \\
\hline \multicolumn{3}{|c|}{ Average } & 11.09 & & 88.91 & & 63.80 & & 36.20 \\
\hline
\end{tabular}

Some sterile pollen was observed in both series of healthy and diseased plants. They were empty in their contents and the walls shrivelled. The average percentage of such abortive pollen taken from healthy and diseased plants is similar to each other $(11.59 \%$ and $11.09 \%$ respectively), and the writer has not experienced in any case such a large amount of abortive pollen as reported by Kostoff, who had observed 48-50 per cent sterile pollen. Neither was abnormally large pollen abundant. Comparing the degree of the germination of apparently normal pollen between healthy and diseased plants, the average percentage of the germinated pollen is rather high in the diseased plants than in the healthy ones, though an exceptionally lower percentage of germinated pollen is observed in the case of No. VII in diseased series.

The writer and his colaborator') observed the occurrence of ' $\mathrm{X}$ Body' or 'Cell Inclusion' in the pollen of mosaic plants, and furthermore the writer experienced positive case in the results of inoculation experiment using the pollen as an inoculum which obtained from diseased plants. Allard ${ }^{2}$ has also proved the presence of virus in the anthers of diseased tobacco and from these facts we may assume the presence of the infective principle in the pollen. However, from the results of the present investigation we may conclude that the formation of abortive pollen is the results of the specificity or special properties of this variety used in the test, ${ }^{3)}$ but not the results of the effects of the virus, and that the function of the pollen, and especially in this case, its germination ability is also never badly influenced by the virus which causes the mosaic disease of tobacco plants.

1) Hirayama, S. and Yuasa, A.: Ann. Phytopath. Soc. Japan, 5 (1935), 197-205.

2) Allard, H. A.: Journ. Agr. Res., 5 (1915), 251-255.

3) A cytological study on this line will be recently reported in another paper. 